never anthorized the use of our names in any publication connected with homoopathy, and are at a loss to know what you refer to.

Other parties publish in the Worcester papers long advertisements of homoopathic preparations, which we do not even expose for sale; but when requested to procure and supply such, we do so, and our refusal would, in effect, be to hand over many of our best customers to the establishments of our rivals in business; therefore, in the desire to oblige those who employ us, we feel equally at liberty to procure a case of globules, or a copy of THE LANCET, for their use, if they desire it.

We beg to add, that we are members of the Pharmaceutical Society of Great Britain, before the council of which we have made the foregoing statement, and have obtained their unanimous sanction of the course we have pursued, under the circumstances stated.

Worcester, Dec. 3, 1851.

$$
\text { We are, Sir, faithfully yours, }
$$

Lea and Perrins.

* * Messrs. Lea and Perrins have a perfect right to choose between the support of the profession and the patrons of globulism, but we opine that they will find it difficult to retain both.-ED. L.

\section{THE NEW CHARTER OF THE COLLEGE OF SURGEONS.}

To the Editor of The LanceT.

SIR,-The extension of the elective franchise in the College of Surgeons to fellows resident in the provinces is intended, it would appear, merely as a compliment to these gentlemen, and not as an available privilege. Those fellows who reside not more than forty or fifty miles from London may, perhaps, readily attend to record their votes, but to the more distant provincial fellows this arrangement will be so inconvenient, that any attempt to place a provincial surgeon on the council will certainly be unsuccessful. The conciliatory spirit in which the council have lately acted leads me to believe that a remonstrance addressed to them on this subject would receive the attention its importance demands. Shonld they, however, refuse to alter this restrictive regulation, the provincial surgeons will not cede quietly a privilege for which they have struggled so long and so strenuously. Another course will be open to them, $\rightarrow$ viz., to petition Sir George Grey to secure to the provincial fellows the right of voting either by proxy, or by balloting-papers transmitted by post, without which the elective franchise in the college would be to this class a nominal and a worthless privilege.

I remain, Sir, your obedient servant,

Much Wenlock, Dec. 1851

W. P. BRoOKES.

${ }^{*}$ * In departing from the plan of voting by papers in the case of Fellows residing at a distance from London, the Council have broken a serious pledge formerly made by this body.-ED. L.

\section{COMPLICATED INJURY TO THE LEG.-QUESTION OF PRACTICE.}

To the Editor of The Lanoet.

SIR,-Willing to contribute what little experience I can for the good of the profession, I enclose the particulars of a case of compound fracture into the knee-joint, which have been called forth by the letter of your correspondent, " $L_{0 .}$ " in the number for November 8th, who asks for opinions of other surgeons, with respect to a case of severe injury of the leg and knee-joint.

In my opinion, "L." was right in recommending amputation; at least, I think he would have been so in the majority of cases of a similar nature, although cases do occur which get well after very severe injury, one of which $I$ will relate.

An elderly woman was admitted into our hospital under the care of one of my colleagues, having fallen from part of our city walls, a height of about sixteen feet, whilst in a state of intoxication. There was compound fracture into the knee-joint, the condyles of the femur and the head of the tibia were broken into several pieces, -in fact, the knee-joint, when handled, felt like a "bag of bones." There was an external wound large enough to remove, without difficulty, several large pieces of bone which were loose, and through which blood and synovia flowed.

Now, Sir, I am, generally speaking, a Conservative in surgery; but in this case I agreed with my colleagues that amputation, as soon as re-action took place, was the only course to be pursued. The husband of the woman gave his consent, but when it was proposed to the patient, she strongly refused, saying she would rather die than lose her leg, and which she maintained when she became sober. The result was, she perfectly recovered, with a partially stiff joint; and during recovery, she had scarcely a bad symptom.

The above, with one or two other cases which I have seen within the last few years, make me now almost always try to save a limb. Hoping you will excuse the above rough sketch of the case, as it has been written from memory, not being able to lay my hands upon my notes of the case,

I remain, Sir, your obedient servant,

Chester, Dec. 1851. T. Britutain.

P.S. I will give you another case, which shows what nature will do when not interfered with by meddlesome surgery. It is that of a boy from the country, admitted with severe injury of the leg. There was compound dislocation of and fracture into the ankle-joint. Mr. Weaver, under whose care the patient was admitted, states that the articulating surfaces of the joints were quite exposed. No operation was performed. The parts were brought into position under the influence of chloroform, and retained there by gentle means; and notwithstanding an attack of erysipelas, which extended nearly to the groin, and terminated in a large collection of matter under the fascia lata, and the extensive suppuration which took place in the joint, the boy is now nearly well. He gets up with splint applied, and will have a very good and useful limb. Several pieces of dead bone have come away.-T. B.

\section{MEETINGS OF THE MEDICAL SOCIETIES IN} LONDON DURING THE ENSUING WEEK.

Nore.-When the day of the month is not specified, no meetings take place.

\begin{tabular}{|c|c|c|}
\hline Societies. & & $\begin{array}{c}\text { Days of } \\
\text { Meeting. }\end{array}$ \\
\hline $\begin{array}{l}\text { Epidemiological, 53, Berners-street } \\
\text { Chemical, 5, Cavendish-square....... } \\
\text { Medico-Botanical, 32, Sackville-st. } \\
\text { Medico-Chirurgical, 53, Berners-st. } \\
\text { Pathological, 33, George-street, } \\
\text { Hanover-square.................... } \\
\text { Hunterian, 4, Bloomfield-street, } \\
\text { Finsbury ............................ } \\
\text { Pharmaceutical, } 17, \text { Bloomsbury-sq. } \\
\text { Harveian, } 64, \text { Edgware-road ......... } \\
\text { South London Medicai, Borough ... } \\
\text { Western Medical and Surgical, } \\
\text { 44, Sloane-street ................. } \\
\text { Medical Society of London, } 32 ., \\
\text { George-street Hanover-square }\end{array}$ & $\begin{array}{l}\text { Mon. } 8 \frac{1}{2} \text { P.M. } \\
\text { Mon. } 8 \text { P.M. } \\
\text { Tuesday. } \\
\text { Tues. } 8 \frac{1}{2} \text { P.M. } \\
\text { Tues. } 8 \text { P.M. } \\
\text { Wed. } 8 \text { P.M. } \\
\text { Wed. } 9 \text { P.M. } \\
\text { Thurs. } 8 \text { P.M. } \\
\text { Thurs. } 8 \text { P.M. } \\
\text { Fri. } 8 \text { P.M. } \\
\text { Sat. } 8 \text { P.M. }\end{array}$ & Dec. 9 \\
\hline
\end{tabular}

\section{ftinedical \$2ems.}

Apothecaries' Halc.-Names of gentlemen who passed their examination in the science and practice of medicine, and received certificates to practise, on Thursday, Nov. 27 th, 1851.

Bayms, Frederick William Harm, Stiffley, Norfolk.

Hales, Thomas, Ford Green, Staffordshire.

WALI, ALFRED, Stratford-on-Avon.

Her Majesty has been pleased to grant, out of her Privy Purse, an annuity of $£ 50$ to the widow, now in her seventy-first year, of the late Dr. David D. Davis, late of 17 Russell-place, Fitzroy-square, the Physician-Accoucheur in attendance at the birth of her present Majesty. Dr. Davis's decease, it will be remembered, took place in 1841 .

Mr. John F. South, President of the Royal College of Surgeons, and Mr. Cæsar Hawkins, Vice-President of the College, had an interview with Sir George Grey yesterday, at the Home-office.

Appointment. - Mr. George P. Rugg, M.R.C.S., and L.A.C., has been appointed House-Surgeon to the Kent Ophthalmic Hospital, in the place of Mr. S. C. Savery, resigned.

Trinity College, Dublin. - The Duke of Cambridge is confidently spoken of as the new Chancellor. The Earl of Rosse, however, is the favourite amongst a very large class of persons. 